\title{
Commodity and Financial Cycles in Resource-based Economies ${ }^{1}$
}

\author{
Marina Tiunova, Bank of Russia \\ tiunovamg@cbr.ru
}

This research analyses the influence of commodity prices on financial cycle parameters in commodity-exporting countries - Australia, Brazil, Canada, Columbia, Russia, and Chile - over the past two decades. One of the key issues discussed herein is the degree to which the extensive implementation of macroprudential policies can reduce the dependence of a country on global commodity cycles. Methodologically, this research is based on the Bayesian Structure Vector Autoregressive Model, structurally identified by means of variable recursive ranking and the Cholesky decomposition of the error covariance matrix. Changes in commodity prices are shown to provoke a stronger response from such financial cycle parameters as the sovereign risk premium and currency exchange rate in resource-based emerging market economies (Brazil, Columbia, Chile, and Russia) than in advanced economies (Canada and Australia). In Brazil, Columbia, Chile, and Russia, increases in commodity prices result in acceleration of the overall lending and external debt growth rate, while in Russia and Brazil they also trigger growth in the share of FX loans. In Australia and Canada, lending parameters react negatively to positive commodity price shocks. In the developing countries that apply macroprudential policy extensively (Columbia and Chile), lending dynamics are less dependent on changes in the global terms of trade. To reduce the impact of the commodity cycle on the financial cycle, the economic policy authorities of emerging market countries should develop national financial markets and introduce macroprudental policy tools more extensively.

Keywords: terms of trade, commodity shocks, credit and financial cycles, emerging markets, foreign currency predominance, macroprudential policies, vector autoregression
Citation: Tiunova, M. (2019). Commodity and Financial Cycles in Resource-based Economies. Russian Journal of Money and Finance, 78(3), pp. 38-70.

doi: $10.31477 /$ rjmf.201903.38

JEL Codes: C32, F38, G15, G28

\footnotetext{
${ }^{1}$ The author would like to express her gratitude to Elizaveta Danilova, Nadezhda Ivanova, Ivan Shevchuk, Olga Pavshok, Evgeny Rumyantsev, and the anonymous reviewers for their assistance, valuable remarks, and comments provided in the process of preparing this research. This research represents the author's personal opinion and does not necessarily reflect the official position of the Bank of Russia. All errors or inaccuracies that might be found in this paper are those of the author.
} 


\section{Introduction}

This research analyses the influence of global commodity market prices on national financial cycles in commodity-dependent countries. The importance of this issue stems from the risk of a boom in national credit markets for resource exporters during high commodity price periods, followed by deleveraging and complications in FX debt servicing if capital inflow to domestic markets stops and national currencies depreciate.

In recent years, the interconnection between the commodity and financial cycles of commodity-exporting countries has been widely discussed in the literature (González et al., 2015; Ftiti et al., 2016; Agarwal et al., 2017; Kinda et al., 2016; Moreno et al., 2014; Alodayni, 2016), and has also been brought up in an analytical note by the Bank of Russia (2017). The growth of commodity prices in the global markets leads to an increase in the inflow of foreign currency earnings to local financial markets and the intensification of economic activity in commodityproducing countries, which, in turn, spurs investments and results in the expansion of lending. FX borrowing and borrowing in the foreign debt market grow as the overall risk level in the financial markets of commodity-producing countries decreases. In the case of a sharp shift in commodity prices, the close correlation between the parameters of the commodity and financial cycles in commoditydependent countries leads to a significant decrease in demand for loans and reduces economic agents' creditworthiness and banks' loan portfolio quality. Moreover, excessive dependence on external funding formed during a period of high commodity prices is associated with the risk of external debt arrears. Thus, a material decrease in domestic lending and the failure to service external debt may cause a volatility surge in national financial markets and a financial crisis.

Consequently, the prevalence of commodities in a country's export structure increases the dependence of its economy on foreign markets and threatens its financial stability. In this regard, it is important to clarify the extent to which the nature and intensity of the influence of global commodity market parameters on resource-based economies' financial cycle indicators vary when there are changes in these countries' economic development, resource dependence, and extent of macroprudential policy (MPP) implementation. ${ }^{2}$ Several articles have been published recently that study similar issues through analysis of data on emerging markets (Cerutti et al., 2017; Cizel et al., 2016; Gambacorta and Murcia, 2017; Bruno et al., 2017; see Section 2).

The novelty of this article lies in its use of alternative tools - the estimation of Bayesian Structure Vector Autoregressive (BSVAR) models - for several commodity-

\footnotetext{
${ }^{2}$ Macroprudential policy is a complex of preventive measures aimed at minimising the risk of a systemic financial crisis or, in other words, the risk that a situation may arise in which a significant proportion of financial sector participants become insolvent or lose liquidity and cannot operate without the support of a monetary authority or a prudential supervision authority (Moiseev and Lobanova, 2013).
} 
exporting countries, including two advanced economies (Australia and Canada). The use of BSVAR tools makes it possible to compare the country-specific sensitivity of financial cycle indicators to commodity price shocks and draw conclusions that supplement and extend the results obtained in papers which analyse panel data solely for developing countries. Thus, this article uses BSVAR models to determine the sensitivity of financial cycle indicators in several countries - Australia, Brazil, Canada, Columbia, Russia, and Chile - to price shocks in commodities that are key to the export structures of the economies in question. We use both the general lending in the economy and the sizes of loans, broken down into specific borrower categories (households and firms) and currencies (national and foreign), as lending activity indicators. Based on the latter, the article arrives at a conclusion concerning the influence of the terms of trade on the level of lending dollarisation in Russia. Moreover, the article analyses the influence of global commodity market conditions on foreign debt load (as an alternative to borrowing in the national credit market), which also reflects the dependence of exporting countries' economies on external conditions. The countries in the sample were selected based on the availability of detailed statistics on their financial cycle indicators, differences in their overall development and resource dependence, and also their different MPP experiences.

The results of this research are consistent with previously published findings (González et al., 2015; Agarwal et al., 2017; Kinda et al., 2016; Pestova and Mamonov, 2016) providing evidence that commodity cycles have a significant influence on financial cycles in resource-based economies. In the majority of the countries analysed, commodity price growth leads to the strengthening of national currencies and the narrowing of sovereign risk premiums on investments in national assets. It should be noted that exchange rate and risk premiums are more sensitive to price movements in countries that have a higher proportion of the key commodity exported in the overall volume of exports and a lower level of MPP implementation. The advanced economies under review (Canada and Australia) show a negative correlation between commodity price trends and lending, which is determined by the countercyclical movement of the central banks' policy interest rates in response to change in the global terms of trade (a countercyclical monetary policy) and the implementation of MPP. In the developing countries which apply MPP extensively (Columbia and Chile), market interest rates also increase in response to the growth of commodity prices, which explains the lower sensitivity of the overall and foreign currency lending growth rates to global commodity market shocks as compared to the developing countries which implement MPP to a lesser extent (Russia and Brazil). In Russia, increasing oil prices accelerate growth in lending, corporate sector foreign debt, and the share of foreign currency loans taken by both households and firms. As a consequence, to reduce the dependence of national economies' and financial systems' parameters on commodity cycles, the economic authorities of emerging markets, and Russia in particular, should put greater effort into developing financial markets and implementing MPP tools more extensively. 
The rest of the paper is structured as follows. Section 2 is dedicated to an overview of the results of theoretical and empirical research on the correlation between commodity and financial cycles in resource-based economies, with a description of the statistical data and analysis methods used. Sections 3 and 4 describe the methods employed in this paper and the statistical data used respectively. Sections 5 and 6 present the estimated sensitivity of the lending activity indicators of commodityexporting countries to global commodity price shocks, along with cross-country comparisons. Section 7 provides conclusions based on the analysis conducted and policy recommendations for resource-based emerging market economies, which could help reduce the correlation between the commodity and financial cycles.

\section{Literature review on the correlation between the commodity and financial cycles and the effectiveness of MPP}

The influence of global commodity price shocks on the dynamics of macroeconomic and financial indicators in resource-based economies has been widely discussed in the literature.

The generally accepted point of view is that export earnings influence the balance of payments and exchange rates in countries with predominantly commoditybased export structures (Basher et al., 2012; Dauvin, 2014; Coudert et al., 2015). Foreign trade shocks influence both the volatility levels of macroeconomic indicators (Makin, 2013; Hegerty, 2016) and the dynamics of business cycles in these countries.

The correlation between the dynamics of commodity prices and lending activity in commodity exporters has been less thoroughly covered in the literature. However, individual theoretical and empirical studies confirm the significant interconnection between global commodity market conditions and lending dynamics, especially in countries with commodity-oriented export structures.

In their research using the Dynamic Stochastic General Equilibrium Model (DSGE), González et al. (2015) show that positive oil price shocks lead to growth of the overall lending level. Ftiti et al. (2016) detect a stable long-term correlation between commodity and credit cycles in a sample of African countries, while in the short- and medium-term only substantial negative commodity price shocks lead to changes in lending indicators.

Among other authors, the Bank of Russia (Bank of Russia, 2017; Sinyakov and Khotulev, 2017) has discussed the mechanism for the commodity cycle's influence on financial stability in commodity-exporting countries. The growth of global commodity prices promotes capital inflow to commodity-exporting countries and the growth of business and investment activity, which, in turn, spurs demand for lending. Moreover, intensification of foreign currency inflow from exports ensures the strengthening of national currencies and the narrowing of risk premiums on investments in national assets. In such conditions, economic agents are more willing 
to borrow, both in national and foreign currencies. Thus, growth of commodity prices can lead to a lending boom and increasing foreign currency predominance in national economies, i.e. to the accumulation of systemic financial risks.

If there is a downturn on the global commodity markets, the amount of liquidity in national financial markets goes down, and the national currencies of commodity exporters depreciate. In these conditions, there is a reduction in credit activity and a deterioration in economic agents' ability to fulfil their foreign currency liabilities. As a result, financial stability is threatened, and the likelihood of a financial crisis increases.

The results of recent empirical research analysing the correlation between commodity and credit cycles in resource-based economies confirm that increased (decreased) commodity prices lead to increased (decreased) lending activity in the countries in question, and that the existence of such a dependence is a source of vulnerability for national financial systems (Agarwal et al., 2017; Kinda et al., 2016; Moreno et al., 2014; Alodayni, 2016).

Research by Agarwal et al. (2017) is dedicated to assessing the impact of terms of trade shocks on volumes of bank lending in 78 developing countries in 2004-2015 using the panel regression model. The authors show that negative commodity price shocks lead to a decrease in the overall level of lending. This effect materialises through supply of and demand for bank loans. A deterioration in the global terms of trade leads to a slowdown in economic activity, which weakens incentives to invest and contributes to a decrease in demand for loans. As business activity decreases, the deposit base of the banking sector shrinks, the ability of economic agents to service debt obligations is reduced, and the quality of banks' assets deteriorates. Consequently, loan supply decreases as well. The negative influence of commodity market dynamics on credit cycle indicators is stronger in countries with lower income and a primarily commodity-based export structure. The greatest credit contraction is experienced by banks with a low level of deposits and a high share of overdue debt.

Kinda et al. (2016) give a more detailed assessment of the correlation between the dynamics of global commodity prices and the vulnerability of the financial sector, also using the panel regression model. Based on analysis of data on 71 countries with a resource-oriented export structure for the period 1997-2013, the authors show that a decrease in commodity prices leads to a decrease in the solvency of economic agents and a deterioration in the quality of commercial banks' balance sheets. There is also a decrease in the liquidity and profitability levels of the banking sector, an increase in the share of overdue debts, an increase in the probability of a banking crisis, and a decrease in the size of provisions for non-performing loans. A commodity price downturn can result in disruption of the balance of the state budget, forcing governments to use their sovereign funds and central banks to use their international reserves to counter threats to financial stability. In conditions of limited liquidity, economic agents (including the state) may resort to borrowing on the international market, which will trigger growth in the proportion of FX debt in the private and public sectors of the economy. Commercial banks' performance 
indicators are more sensitive to negative commodity shocks in countries with poorquality state institutions, a lack of effective fiscal and macroprudential policies, and a low level of manufacturing and export diversification.

Thus, the dependence of national financial systems on external conditions poses a challenge for the economic authorities of commodity-producing countries. Sinyakov and Khotulev (2017) note that optimal economic policy in commodityexporting countries should include an inflation targeting regime (and, accordingly, a floating exchange rate), a conservative fiscal policy with a fiscal rule, and a set of macroprudential regulation measures.

Moreover, research by Menna and Tobal (2018) concludes that monetary policy tools can turn out to be insufficient to curb financial stability threats in financially open developing economies. The authors draw this conclusion on the basis of calculations under a theoretical New Keynesian model, using statistical data on Mexico's economy. In response to positive external shocks leading to the improvement of financial cycle indicators, monetary authorities can raise interest rates in an attempt to limit the possible increase in internal lending. However, in the absence of restrictions on cross-border capital flows, and given the high dependence of developing economies on foreign funding (due to the relative underdevelopment of national financial markets), interest rate hikes can provoke an inflow of foreign capital to the domestic markets of developing countries and, contrary to expectations, lead to increased internal lending. This may increase leverage and foreign debt, and add to the accumulation of systemic risks. For this reason, the authors conclude that, in response to positive shocks from the external sector, an optimal strategy for the monetary authorities of countries with open capital accounts would involve reducing interest rates rather than increasing them.

After the global financial crisis of 2007-2009, an approach according to which economic authorities should pursue a countercyclical macroprudential policy to prevent the accumulation of financial system risks is becoming more and more widespread: the tightening of MPP by the regulator during the growth phase of a credit cycle will result in the growth of prices for lending resources, which will inhibit a boom in the financial market.

González et al. (2015) note that, in order to control lending activity during the growth phase of a financial cycle, monetary policy tools (short-term interest rates and foreign currency interventions) and macroprudential policy tools (financial regulation measures influencing the level of market interest rates) are used together, and that the supplementation of monetary policy with macroprudential tools ensures more effective control of lending during the growth phase of a financial cycle. ${ }^{3}$

Empirical research by Cerutti et al. (2017) and Cizel et al. (2016) provides a detailed analysis of the influence of MPP on lending activity and the financial

\footnotetext{
${ }^{3}$ In this situation, interindustry discrepancies in the structure of economies strengthen due to the more substantial lending decrease in the tradable sector and the continuing growth of lending in the non-tradable sector. However, the scale of this effect is insignificant.
} 
sector, based on cross-country comparisons using panel data regressions. Cerutti et al. (2017) assess the effectiveness of the MPP implemented in 119 countries of various levels of development in 2000-2013. The authors conclude that the use of MPP tools promotes slowdowns in lending growth, especially in the consumer lending sector. The tightened internal lending conditions resulting from MPP implementation stimulate external fund raising in foreign markets. This is why the efficiency of MPP is higher in countries with relatively less developed financial systems and a closed capital account. The effectiveness of MPP is characterised by asymmetry of influence: the influence of regulatory authorities' policy tools is higher during the growth phases of financial cycles.

The effectiveness of macroprudential regulation of economies has also been confirmed in research dedicated to the economies of specific regions: eight North and South American countries in an article by Gambacorta and Murcia (2017) and twelve Pacific Rim countries by Bruno et al. (2015).

Thus, the results of empirical research show that MPPs are effective with regard to controlling the growth of lending and limiting systemic financial risks. At the same time, the use of MPP does not distort the effect of other economic policy tools. Richter et al. (2018) note that the implementation of MPP tools is accompanied by only a limited reaction from inflation and output, especially in advanced economies; in other words, the pursuit of an effective MPP does not prevent the achievement of central banks' inflation and output targets.

Research publications dedicated to the Russian economy also analyse the influence of the global commodity market situation on the dynamics of national macroeconomic variables. The authors of the majority of studies arrive at the conclusion that the improvement of global terms of trade leads to the expansion of economic activity. Based on Russian data for 1995-2009, Ito (2012) demonstrates that a $1 \%$ increase in global oil prices leads to GDP growth of $0.44 \%$ in the long term. Increased export income leads to increased consumption, investments, and GDP (Malakhovskaya and Minabutdinov, 2013). The results of a study by Polbin (2017) demonstrate that, contrary to the traditional opinion, growth of oil prices leads to growth of gross production only in the short term (2-2.5 years), while in the mid term, this correlation becomes negative.

That said, only a limited number of studies on the influence of global oil cycle parameters on the level of lending activity in Russia has been carried out. In their article, Pestova and Mamonov (2016) use the BVAR model of the Russian economy to demonstrate, on the basis of 2000-2015 data, that an increase in the Brent oil prices leads to increased gross output, as well as to increased external debt in the corporate sector and an increased overall level of consumer and corporate lending (these effects peak one and two years after the shock respectively). Research by Lomivorotov (2014) does not find any statistical correlation between the dynamics of oil price indicators and overall lending in Russia. Nevertheless, the author includes the volume of lending in his model and explains, on a theoretical level, 
that external shocks (including the global energy market situation) influence Russia's financial variables.

Despite the availability of evidence of a correlation between commodity cycles and financial stability in commodity-exporting countries, and of the role of macroprudential policies in these countries, this area of research is fairly new. This study contributes to the literature in the following regards.

First, it aims to quantify the statistically significant correlation between the parameters of commodity and credit cycles using BSVAR models for six selected resource-dependent countries, including advanced economies. A review of the literature indicates the lack of a sufficient range of studies containing econometric assessment of those effects and making cross-country comparisons. The empirical results of the research confirm the mechanism for the correlation between commodity and financial cycles described in an analytical note by the Bank of Russia (2017).

Second, this study considers more lending activity indicators than other research: not only is overall lending volume analysed, but volumes of lending in national and foreign currencies are also considered, along with lending volumes broken down into borrower categories, which makes it possible to assess the sources of vulnerabilities and risks for specific market segments of the countries in question in detail. The list of lending indicators for each of the countries is defined by the availability of data, and is therefore most complete for Russia. It is especially important to identify the influence of oil market shocks on dollarisation parameters in Russia's banking sector.

Third, the results obtained for specific countries are grouped based on the extent of these countries' economic development into advanced economies (Australia and Canada) and emerging markets (Brazil, Chile, Columbia, Russia).

Fourth, observable correlations between the dynamics of commodity price indicators and lending growth rates are found to be consistent with the actual experience of MPP implementation in each of the countries, which enables the conclusion to be drawn that the pursuit of a countercyclical MPP contributes to reducing a country's vulnerability to the situation on global commodity markets.

\section{Research methodology}

To conduct the research, time series models based on various credit cycle indicators (depending on data availability, see below) are constructed for each of the six countries with a significant share of commodity exports in their overall export structures.

Methodologically, the research is based on the BSVAR model. The vector autoregression (VAR) mechanism makes it possible to take endogenous relationships between different macroeconomic variables into account. The structural identification of the model facilitates qualitative analysis of the 
statistically significant correlations observed between the analysed variables. The Bayesian approach to the assessment of VAR model coefficients eliminates the problem of excessive model parametrisation (the 'dimensionality curse').

We have decided to construct a model with a large number of regressors, as this will increase the volume of information available for analysis, which will in turn increase the reliability of the estimated of relationships between individual macroeconomic variables. This enables us to avoid the potential occurrence of errors and the establishment of false correlations between model variables that contradict macroeconomic theory (Bernanke and Boivin, 2003). ${ }^{4}$ This issue is a key for the analysis of Russian data, since in the past 20 years the Bank of Russia has changed its monetary policy stance several times. For this research, it is especially important to take the various monetary policy tools of the Bank of Russia into account, as we are analysing the reaction of interest rates to shocks in the commodity market and drawing a conclusion concerning the performance of lending activity indicators in accordance with the phase of the commodity cycle.

The basic specification for a VAR model with $m$ variables and $p$ lags is written as follows (a structural specification of the model is provided below):

$$
Y_{t}=B_{\text {const }}+B_{1} Y_{t-1}+B_{2} Y_{t-2}+\cdots+B_{p} Y_{t-p}+\varepsilon_{t}
$$

where $\varepsilon_{t} \sim N(0, \Sigma), Y_{t}=\left(y_{1 t}, y_{2 t}, \ldots, y_{m t}\right)^{\prime}$ is the vector of endogenous variables of the dimensionality $m(\mathrm{t}=1, \ldots, \mathrm{T}), B_{\text {const }}=\left(b_{1}, b_{2}, \ldots, b_{m}\right)^{\prime}$ is the constant vector of the dimensionality $m$, and $B_{l}$ is the matrix of autoregressive coefficients $m \times m$, where $l$ is the number of the lag from 1 to $p$.

After grouping $B=\left[B_{\text {const }} B_{1} \ldots B_{p}\right]^{\prime}$ and $X_{t}=\left[1 Y_{t-1}^{\prime} \ldots Y_{t-p}^{\prime}\right]^{\prime}$, the reduced form of VAR is obtained:

$$
Y_{t}=B^{\prime} X_{t}+\varepsilon_{t}
$$

The need for Bayesian regularisation of the model parameters is explained by the use of a relatively wide range of regressors (around 10 variables) with a maximum lag depth ( 5 periods for quarterly data-based models and 13 periods for models based on monthly statistical data).

The Bayesian formula is as follows:

$$
p(B, \Sigma \mid Y)=\frac{p(B, \Sigma) p(Y \mid B, \Sigma)}{p(Y)}
$$

where $p(B, \Sigma \mid Y)$ is the density of posterior distribution; $p(B, \Sigma)$ is the prior density of model parameters, $p(Y \mid B, \Sigma)$ is the likelihood function of a vector autoregression task, and $p(Y)$ is the distribution density of actual data.

\footnotetext{
${ }^{4}$ At the same time, we admit that increasing the number of variables leads to a nonlinear extension of the range of parameters assessed and a narrowing of the prior distribution of model coefficients during Bayesian assessment of the model.
} 
Thus, the Bayesian approach is based on a combination of actual data information and prior information on the distribution of model parameters. Taking into account prior information, the researcher obtains an a posteriori distribution of model parameters.

The next phase of Bayesian assessment of a model is the selection of the appropriate type of prior distribution of model coefficients. In this study, an independent normal inverted prior Wishart distribution will be used as the prior distribution of parameters. In accordance with this distribution, the vector $b$ of the model coefficients is distributed in accordance with the normal distribution law (with a prior average $\bar{b}_{0}$ and a parameter covariance matrix $H$ ), and the error covariance matrix $\Sigma$ is distributed in accordance with the inverted Wishart distribution law with the prior parameters $\bar{S}$ and $\alpha$ (number of degrees of freedom) (Blake and Mumtaz, 2017):

$$
\left\{\begin{array}{c}
b=\operatorname{vec}(B) \sim N\left(\bar{b}_{0}, H\right), \\
\Sigma \sim \operatorname{IW}(\bar{S}, \alpha) \\
b \text { and } \Sigma \text { are independent }
\end{array}\right.
$$

Using a priori ideas makes it possible to take the non-stationary nature of macroeconomic variables into account. The elements of the a priori coefficient matrix of the vector autoregression model in abridged form $\bar{B}\left(\bar{b}_{0}=\operatorname{vec}(\bar{B})\right)$ are as follows (Blake and Mumtaz, 2017, p. 31; Pestova and Mamonov, 2016, p. 61):

- the equation for each particular variable has non-zero coefficients only for the first lag of this variable;

- the equation for each non-stationary variable in the model has the coefficients for the first lag of this variable equal to 1 .

This can be presented as follows:

$$
\begin{aligned}
& \left(\begin{array}{c}
V I X_{t} \\
\text { Brent }_{t} \\
\ldots \\
\operatorname{CDS}_{t}
\end{array}\right)=\left(\begin{array}{c}
0 \\
0 \\
\ldots \\
0
\end{array}\right)+\left(\begin{array}{cccc}
\bar{B}_{21} \neq 0 & 0 & \ldots & 0 \\
0 & \bar{B}_{32} \neq 0 & \ldots & 0 \\
\ldots & \ldots & \ldots & \ldots \\
0 & 0 & \ldots & \bar{B}_{(m+1) m} \neq 0
\end{array}\right) \\
& \times\left(\begin{array}{c}
V I X_{t-1} \\
\text { Brent }_{t-1} \\
\ldots \\
\operatorname{CDS}_{t-1}
\end{array}\right)+\left(\begin{array}{cccc}
0 & 0 & \ldots & 0 \\
0 & 0 & \ldots & 0 \\
\ldots & \ldots & \ldots & \ldots \\
0 & 0 & \ldots & 0
\end{array}\right)\left(\begin{array}{c}
V I X_{t-2} \\
\text { Brent }_{t-2} \\
\ldots \\
C D S_{t-2}
\end{array}\right)+\ldots+\left(\begin{array}{c}
\varepsilon_{V I X} \\
\varepsilon_{B r e n t} \\
\ldots \\
\varepsilon_{C D S}
\end{array}\right) .
\end{aligned}
$$

Matrix $\bar{B}$ (with $(1+m p)$ lines and $m$ columns) will be:

$$
\left(\begin{array}{cccccc}
0 & 0 & 0 & 0 & \ldots & 0 \\
\bar{B}_{21}=1 & 0 & 0 & 0 & \ldots & 0 \\
0 & \bar{B}_{32}=1 & 0 & 0 & \ldots & 0 \\
0 & 0 & \bar{B}_{43}=1 & 0 & \ldots & 0 \\
0 & 0 & 0 & \bar{B}_{54}=1 & \ldots & 0 \\
\ldots & \ldots & \ldots & \ldots & \ldots & \ldots \\
0 & 0 & 0 & 0 & \ldots & 0
\end{array}\right) .
$$


The covariance matrix of parameters $H$ is set as follows. The dimensionality of the covariance matrix of parameters $H$ is $d=((m(m p+1)) \times(m(m p+1)))$. According to Bank of England economists Blake and Mumtaz (2017), every element of the diagonal covariance matrix of parameters in the model $H$ equals $\left(\sigma_{i} \lambda_{4}\right)^{2}$ for the constant, $\left(\frac{\lambda_{1}}{l^{\lambda_{3}}}\right)^{2}$ for $i=j$ and $\left(\frac{\sigma_{i} \lambda_{1} \lambda_{2}}{\sigma_{i} l_{3}}\right)^{2}$ for $i \neq j, i$ and $j=1 \ldots m$ (the number of variables in the model), where the index $i$ corresponds to the number of the dependent variable in each of its equations, and the index $j$ corresponds to the number of the independent variable in the equation of each dependent variable.

Moreover, to model economic processes in small open economies using the independent normal inverted prior Wishart distribution, limits can be imposed on coefficients of external sector variables (Blake and Mumtaz, 2017, pp. 37-41) in order to exclude the effect of internal real, financial, and monetary variables on the external block indicators.

The list of variables will be described in more detail in the next section. However, for clarity, consider the following. Some specification of the model includes 11 variables (VIX index, commodity price, US/EU GDP, internal GDP, domestic inflation, external debt, interest rate, lending, monetary base, currency rate and credit default swap (CDS) spread) with 13 lags. The dimensionality $d$ of the covariance matrix of parameters $H$ is $1584 \times 1584$. We take the values of those $H_{d d}$ corresponding to the relation between the external sector variables and other macroeconomic variables to be close to zero. As a result, the dynamics of each of the three exogenous variables (the VIX index, commodity price and USA/EU GDP) depend only on its own lags.

Then, to show that VIX (which comes first in the matrix of input data) depends only on its own lags, we approximate all elements $H_{d d}$ to zero, where $d$ takes a value from 1 to 144, except for $d=1$ (for the constant) and $d=(2+z \cdot 11)$, where $z=0, \ldots, 12$ :

$$
\left.\begin{array}{cccccccccccccccc}
H_{11} & 0 & 0 & \ldots & 0 & 0 & 0 & \ldots & 0 & \ldots & 0 & 0 & \ldots & 0 & \ldots \\
0 & H_{22} & 0 & \ldots & 0 & 0 & 0 & \ldots & 0 & \ldots & 0 & 0 & \ldots & 0 & \ldots \\
0 & 0 & H_{33} & \ldots & 0 & 0 & 0 & \ldots & 0 & \ldots & 0 & 0 & \ldots & 0 & \ldots \\
\ldots & \ldots & \ldots & \ldots & \ldots & \ldots & \ldots & \ldots & \ldots & \ldots & \ldots & \ldots & \ldots & \ldots & \ldots \\
0 & 0 & 0 & \ldots & H_{1212} & 0 & 0 & \ldots & 0 & \ldots & 0 & 0 & \ldots & 0 & \ldots \\
0 & 0 & \uparrow & 0 & \ldots & 0 & H_{1313} & 0 & \ldots & 0 & \ldots & 0 & 0 & \ldots & 0 & \ldots \\
0 & 0 & 0 & \ldots & 0 & 0 & H_{1414} & \ldots & 0 & \ldots & 0 & 0 & \ldots & 0 & \ldots \\
\ldots & \ldots & \ldots & \ldots & \ldots & \ldots & \ldots & \ldots & \ldots & \ldots & \ldots & \ldots & \ldots & \ldots & \ldots \\
0 & 0 & 0 & \ldots & 0 & 0 & 0 & \ldots & H_{3333} & \ldots & 0 & 0 & \ldots & 0 & \ldots \\
\ldots & \ldots & \ldots & \ldots & \ldots & \ldots & \ldots & \ldots & \ldots & \ldots & \ldots & \ldots & \ldots & \ldots & \ldots \\
0 & 0 & 0 & \ldots & 0 & 0 & 0 & \ldots & 0 & \ldots & H_{134134} & 0 & \ldots & 0 & \ldots \\
0 & 0 & 0 & \ldots & 0 & 0 & 0 & \ldots & 0 & \ldots & 0 & H_{135135} & \ldots & 0 & \ldots \\
\ldots & \ldots & \ldots & \ldots & \ldots & \ldots & \ldots & \ldots & \ldots & \ldots & \ldots & \ldots & \ldots & \ldots & \ldots \\
0 & 0 & 0 & \ldots & 0 & 0 & 0 & \ldots & 0 & \ldots & 0 & 0 & \ldots & H_{144144} \\
\ldots & \ldots & \ldots & \ldots & \ldots & \ldots & \ldots & \ldots & \ldots & \ldots & \ldots & \ldots & \ldots & \ldots & \ldots
\end{array}\right)
$$


The matrix $H$ for the second variable (commodity price) and the third variable (USA/EU GDP) is filled in the same way. For the second variable, we assume all elements $H_{d d}$ to be equal to zero, where $d$ takes a value from 145 to 288, except for $d=145$ (for the constant) and $d=(147+z \cdot 11)$, where $z=0, \ldots, 12$. For the third variable (USA/EU GDP), we assume all elements $H_{d d}$ to be equal to zero, where $d$ takes a value from 289 to 432 , except for $d=289$ (for the constant) and $d=(292+z \cdot 11)$, where $z=0, \ldots, 12$.

Empirical calculations are performed in the Matlab software package using code from Kolb (2016) and Blake and Mumtaz (2017).

The numerical values for the hyperparameters of prior distribution $\left(\lambda_{1}, \lambda_{2}\right.$, $\lambda_{3}$ and $\lambda_{4}$ ) are selected in accordance with certain conceptual considerations (Demeshev and Malakhovskaya, 2016).

The parameter $\lambda_{1}$ describes the overall 'rigidity' of prior distribution. The closer $\lambda_{1}$ is to 0 , the more the researcher relies on prior information concerning the distribution of model indices and the less he or she relies on the actual information contained in the data. In empirical publications, indicator values are established in accordance with model dimensionality. That is why, in this case, the parameter $\lambda_{1}$ equals 0.1 , as for a middle-dimensionality BSVAR.

The Bayesian cross-regularisation parameter $\lambda_{2}$ reflects the 'rigidity' of prior distribution in relation to the current and lag values of other model regressors compared to the current variable. In other words, this parameter is responsible for the importance of other variables in the description of the dynamics of a certain variable compared to its own values (this variable may also abide by the 'random walk' law and be defined to a greater extent by its prior values than by other factors). The value of the parameter $\lambda_{2}$ is set at 0.5 .

The hyperparameter $\lambda_{3}$ reflects the relative importance of lag values compared to its current value. The higher the value of $\lambda_{3}$, the faster the decrease of prior dispersion values as the lag number increases. The parameter $\lambda_{3}$ is assigned a value of 1 .

The hyperparameter $\lambda_{4}$ shows the relative 'rigidity' of constant distribution. Relatively high values of constant dispersion mean that tighter limitations are applied to its value. In this case, $\lambda_{4}$ equals 1,000 , which also tallies with the results of empirical research (Pestova and Mamonov, 2016).

The error covariance matrix $\Sigma=\operatorname{var}\left(\begin{array}{c}\varepsilon_{1 t} \\ \varepsilon_{2 t} \\ \ldots \\ \varepsilon_{n t}\end{array}\right)$. The matrix $\bar{S}$ (the parameter of the prior distribution scale of the matrix $\Sigma$ ) takes a diagonal form: the main diagonal elements are estimates of the standard error deviations of each model variable in accordance with the AR(1) first-order autoregression models for each of the endogenous variables.

The a priori number of degrees of freedom in the error covariance matrix $\Sigma$ is calculated as follows: $\alpha=m+1$.

Unconditional posterior distribution parameters may not be represented analytically, which is why the Gibbs algorithm is used for calculations. The conditional posterior distribution parameters are as follows: 


$$
\left\{\begin{array}{r}
b \mid \Sigma, Y \sim N(\overline{\bar{b}}, \overline{\bar{H}}), \\
\Sigma \mid b, Y \sim I W(\overline{\bar{S}}, \overline{\bar{\alpha}}),
\end{array}\right.
$$

where $\overline{\bar{\alpha}}=\alpha+T$ (number of observations),

$\overline{\bar{S}}=\bar{S}+\left(Y_{t}-B^{\prime} X_{t}\right)^{\prime}\left(Y_{t}-B^{\prime} X_{t}\right)$;

$\overline{\bar{H}}=\left(H^{-1}+\Sigma^{-1} \otimes X_{t}^{\prime} X_{t}\right)^{-1}$;

$\overline{\bar{b}}=\overline{\bar{H}} \cdot\left(H^{-1} \bar{b}_{0}+\left(\Sigma^{-1} \otimes\left(X_{t}^{\prime} X_{t}\right)\right) \hat{b}\right)$,

where $\hat{b}=\operatorname{vec}\left(X_{t}^{\prime} X_{t}\right)^{-1} X_{t}^{\prime} Y_{t}$.

Structurally, the VAR model may be written as follows:

$$
A Y_{t}=F_{\text {const }}+F_{1} Y_{t-1}+F_{2} Y_{t-2}+\cdots+F_{p} Y_{t-p}+D v_{t},
$$

where $B_{\text {const }}=A^{-1} F_{\text {const }}, B_{i}=A^{-1} F_{i}(i=1 \ldots p), \varepsilon_{t}=A^{-1} D v_{t^{\prime}}, E\left(v_{t} v_{t}^{\prime}\right)=I$, and $A^{-1} D D^{\prime}\left(A^{-1}\right)^{\prime}=\Sigma$.

Consequently, to identify structural shocks (the impact of isolated shocks of each endogenous variable on all model variables), the only decomposition into the product of matrices $A^{-1} D D^{\prime}\left(A^{-1}\right)^{\prime}=\Sigma$ for the unit matrix $A$ and for the lower triangular matrix $D$ has to be found.

The structural identification of the model is based on recursive ranking of variables (sorting them in accordance with the speed of the shock reaction) and Cholesky orthogonalisation. The recursive ranking method is often used for structural identification of large macroeconometric models (Christiano et al., 1999; Bańbura et al., 2010).

This research assesses the influence of changes in global terms of trade on the parameters of national financial cycles in small open economies. In other words, in our research, external sector variables are set as exogenous variables with respect to internal variables, and hence do not react to internal variable shocks. In general, the following order of variable sorting has been chosen, from the 'most exogenous' to the 'most endogenous' (the parameters are listed in accordance with their location within the endogenous variable vector):

- External sector variables: global market volatility indicator, commodity prices, global GDP;

- National macroeconomic variables: domestic GDP and inflation;

- National financial variables: external debt, interest rate, lending, monetary base, currency exchange rate, risk premium.

Hence, within an endogenous variable vector, the price of a commodity (terms of trade) is placed in second position, and the credit risk indicator is placed in eighth position.

Qualitative interpretation of model results is based on analysis of the impulse response functions of credit cycle indicators in response to commodity price shocks and on the calculation of the maximum commodity price shock elasticities of lending indicators. Credible intervals for median responses are provided in the 16th and 84th percentiles. 
Each time series model includes one lending activity indicator; hence, estimates of the sensitivity of different credit cycle parameters to changes in global terms of trade are obtained on the basis of various BSVAR model specifications. Moreover, depending on the availability of statistical information on different financial cycle indicators, we assess models using either quarterly or monthly data frequency.

\section{Data}

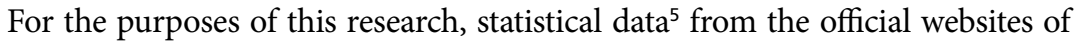
national central banks, statistical services, the International Monetary Fund (IMF), the Bank for International Settlements (BIS), and Bloomberg are used. The countries considered include large exporters, both advanced economies and emerging markets (Table 1): Russia, Columbia, Chile, Canada, Australia, and Brazil. ${ }^{6}$

The rationale for the inclusion of these countries in the sample for this research is as follows. First, we believe it necessary to include countries with different levels of economic development in the sample: both developed and emerging markets. The countries we consider include Canada and Australia in the former category, and Brazil, Chile, Columbia, and Russia in the latter. Second, we consider it important to select countries specialising in different types of commodities: oil, copper, iron ore, and coal. Third, we have attempted to focus on the analysis of countries where accurate statistical data is publicly available. Finally, with regard to developing countries, we aim to compare the reaction of credit cycles in countries where MPP tools have been used extensively and for a long time (Columbia and Chile) with data on countries in which these tools have been employed for a shorter time (Brazil and Russia).

Table 1. Share of the key export item in total export earnings in commodity-exporting countries in 2017

\begin{tabular}{lll} 
Country & Export category & $\mathbf{2 0 1 7}$ \\
\hline Chile & Copper & $58 \%$ \\
\hline Russia & Crude oil and petroleum products & $42 \%$ \\
\hline Columbia & Crude oil and petroleum products & $35 \%$ \\
\hline Australia & Coal & $16 \%$ \\
\hline Canada & Crude oil & $13 \%$ \\
\hline Brazil & Iron ore & $9 \%$ \\
\hline
\end{tabular}

Source: author's calculations based on Bloomberg data

\footnotetext{
${ }^{5}$ The length of the time series is January 2003-November 2017 for Chile, January 2004-November 2017 for Russia, Columbia, Canada, and Australia, and January 2005-November 2017 for Brazil.

${ }^{6}$ During the period covered by this study, all the countries have been characterised by a comparable monetary policy framework: an inflation targeting (IT) regime (carrying out an independent monetary policy with free movement of global capital flows) and a floating currency exchange rate. Canada shifted to IT in 1991, Australia in 1993, and Brazil, Chile, and Columbia in 1999 (Martínez, 2008). Among the countries under review, only Russia adopted IT relatively recently, in 2014; therefore, for Russia we additionally assess the relation between the parameters of the commodity and financial cycles in periods of homogeneous monetary policy.
} 
Each of the time series models includes the following variables (listed from the 'most exogenous' to the 'most endogenous'):

External sector variables:

1. The imputed volatility of the S\&P 500 stock index in the USA (the VIX index of the Chicago Option Exchange) ${ }^{7}$.

2. Commodity prices (prices per barrel of Brent crude oil or per metric ton of copper, coal, or iron ore in USD).

3. Real GDP of the USA (or the EU).

Internal macroeconomic variables:

4. Real GDP (for quarterly data-based models) or real industrial production index (for monthly data-based models).

5. Consumer Price Index (CPI) in national currency.

Internal financial variables (financial cycle variables):

6. Interest rate.

7. Monetary base (broad definition).

8. Credit cycle indicator (see below).

9. Nominal USD - national currency exchange rate (as this indicator grows, the national currency weakens).

10. Risk premium (the spread on five-year sovereign CDS).

In the specifications of models based on Russian monthly data, we use sectoral loan interest rates for up to one year, which correspond to certain lending components (lending for special categories of borrowers and lending currency).

In the specifications of models based on Russian quarterly data (with indicators of external debt and the share of loans in GDP), more general financial market indicators are used, such as the interest rates of the interbank lending market MIACR for overnight rouble loans.

In the specifications of models based on data from other countries aside from Russia, indicative interest rates on short-term and medium-term loans to the private sector (the IMF Lending Rate ${ }^{8}$ ) are used.

Thus, generating a model based on Russian data we take into account both the Bank of Russia's monetary policy and credit market conditions (an appropriate loan rate is used for individual lending components). For other countries, for data comparability purposes, data from a single source are used

\footnotetext{
7 The VIX volatility index reflects sentiments on the global financial markets and the risk appetite of global investors. This indicator also reflects global monetary policy (including leading central banks, in particular the US Federal Reserve System), which has a significant effect on financial markets in developing countries. Empirical research confirms that the policy pursued by the US Federal Reserve System has a statistically significant effect on the expectations of financial market participants. Krieger et al. (2012) show that, after meetings of FOMC members, VIX decreased substantially, as the regulator's decisions lessened uncertainty with respect to the future path of interest rates in the US. Rey (2018) points out that VIX changes together with the global financial cycle, in which the monetary policy of leading global economies is one of the key determinants.

${ }^{8}$ See http://datahelp.imf.org/knowledgebase/articles/810906-what-is-the-lending-rate, http://data.imf.org/regular.aspx?key=61545855.
} 
for short-term and medium-term interest rates, which are also affected by monetary policy tools. ${ }^{9}$

The following credit cycle indicators are used to assess the influence of changes in the terms of trade on the level of credit risk in Russia:

- The annual overall growth rate in roubles and in a foreign currency in which individuals and legal entities borrow $\left(\% \mathrm{YoY}^{10}\right)$.

- The shares of overdue debt under loans to individuals and legal entities in roubles and foreign currency (percentage points, p.p.).

- The share of foreign currency loans to individuals and legal entities (p.p.).

- The annual growth rate of the external debt of the corporate sector (\% YoY)

- The annual growth rate of the loan-to-GDP ratio (\% YoY).

The following credit cycle indicators are used to assess the influence of changes in the terms of trade on the level of credit risk in other countries:

- The annual growth rate of the overall lending level (\% YoY).

- The annual growth rate of consumer and corporate lending (\% YoY).

- The annual growth rate of foreign currency lending (\% YoY).

- The annual growth rates of the shares of foreign currency loans (\% YoY).

- The annual growth rate of external debt (of the private sector, the corporate sector, and overall) (\% YoY).

- The annual growth rate of the loan-to-GDP ratio (\% YoY).

Differences in the credit risk indicators which we include in empirical models for each of the countries, and the reaction of which to commodity shocks we assess, stem from the availability of statistical data in open sources. We include the most indicators for Russia, as a vast quantity of Russian statistical data is available.

Real economy indicators are provided against the base year 2010 (the values of the real indicators equal 100\% in January (or Q1) 2010). Data on the overall foreign currency lending level and its share in the loan portfolio of countries other than Russia are obtained from the Financial Soundness Indicators of the IMF. When calculating the indices of foreign currency predominance and the rates of foreign currency lending changes, data adjusted for changes in the exchange rate are used. The time series are seasonally adjusted in the Eviews package using the X-12 filter.

\footnotetext{
${ }^{9}$ The influence of monetary policy on interest rates for various terms is a subject of scholarly debate. In a theoretical paper, Chun (2011) shows that changes in the expectations of market participants as a result of the actions of fiscal authorities cause changes in the yield of government bonds with long maturity periods. Empirical work by Bernanke et al. (2005) shows that changes in the Federal Funds rate made by the US Federal Reserve System have a significant effect on the dynamics of the yields of treasury bonds with a maturity period of five years. In developing countries, the sensitivity of yields on long bonds to monetary policy shocks is lower than in countries with more developed financial markets and, consequently, a more effective mechanism of monetary policy transmission. However, research based on Russian data reveals that monetary policy has a significant effect on yields on longterm securities. Using the BVAR model of the Russian economy, Lomivorotov (2014) shows that, on average, a $50 \mathrm{bp}$ increase in the REPO rate causes a $0.1-0.15 \%$ increase in the yield on 10 -year federal government bonds.

10 The annual growth rate of an indicator (\% YoY).
} 
To perform the calculations, all data series except interest rates are provided as annual growth rates in percent. ${ }^{11}$ The shares of overdue debt in the overall loan portfolio and the foreign currency predominance indices of loans to individuals and legal entities for Russia are also included in the model in percent. Some of the data we use are nonstationary, but the Bayesian approach to VAR assessment makes it possible to take nonstationarity into account when establishing the prior distribution of model coefficients (Bańbura et al., 2010; Pestova and Mamonov, 2016).

\section{Assessment of the commodity price elasticity of credit cycle indicators}

Statistical data on each of the economies under consideration is used as the basis for assessing the impulse response functions of credit cycle indicators in response to commodity price shocks. In the case of a significant impulse response (median impulses and credible intervals do not include the zero point), the maximum possible value of the commodity price elasticity of the credit cycle indicator is calculated. Tables 2-7 show the summary data for each of the countries considered.

Each of Tables 2-7 contains the estimated commodity price elasticities of credit cycle indicators. An elasticity of X means that, if the annual growth rate of a commodity price accelerates by 1 p.p., the growth rate of the credit cycle indicator will increase by X p.p. Besides elasticities, Tables 2-7 provide information on the periods in which commodity market shock has had the maximum impact on credit cycle indicators.

\subsection{Russia}

According to the Federal Customs Service of Russia, earnings from exports of crude oil and petroleum products account for a significant share of the country's exports (42\% in 2017) (Figure 1). For this reason, to approximate terms of trade shocks, we will use the price of Brent crude oil in US dollars. Calculations for Russia are performed using statistical data for 2004-2017.

The results of assessment of the sensitivity of credit cycle indicators to oil shocks are provided in Table 2. Graphs of the impulse response functions on the basis of which elasticity coefficients are calculated are provided in Figure 1 in the Appendix. The results of assessment of impulse functions show that positive oil price shocks lead to a decrease in the overall risk level in the Russian

\footnotetext{
${ }^{11}$ Using data in the form of the indicator's annual growth rates makes it possible, on the one hand, to preserve information about trend changes in the variable (as compared to monthly growth indicators) and, on the other hand, to reduce the duration of empirical calculations in a large macroeconomic model (as compared to data in levels). An example of the use of this method of data processing is Bergholt et al. (2019). Moreover, using the statistics on lending and its components in the form of annual growth rates is valuable for financial stability research, as they are a generally accepted indicative measure of risk (Alessi and Detken, 2018; Bank for International Settlements, 2019).
} 
financial market (narrowing of the CDS spread) and the strengthening of the rouble against the US dollar through additional inflow of export earnings to the national financial market and improvement of the balance of payments. In general, the dynamics of these macroeconomic variables correspond to to the phenomena and effects we observe in other commodity-exporting countries (e.g., see Sinyakov and Khotulev, 2017).

Figure 1. Russia's export structure in 2006-2017 (\%)

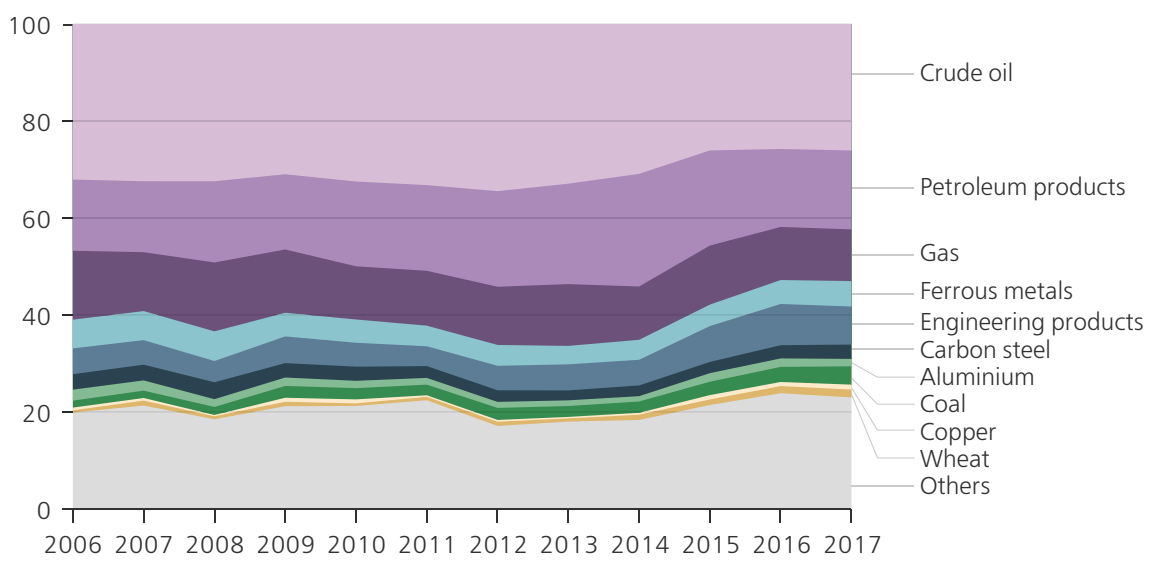

Source: Federal Customs Service of Russia

It should be noted that the interest rate of the interbank lending market decreases when global oil market dynamics improve, which means that, during the growth phase of a commodity cycle, lending conditions in the Russian financial market ease. This result may be related to the fact that, during the period analysed, the Bank of Russia switched to interest rate management only at the end of 2013 (the switch to the inflation targeting policy was announced in November 2014), that the Ministry of Finance's implementation of the countercyclical fiscal rule in Russia is relatively recent, and that the country currently has only brief experience of implementing macroprudential regulation.

Thus, during the entirety of 2004-2017, the easing of financial conditions in the Russian market was accompanied by the expansion of lending in Russia. In response to the growth of oil prices, the growth rate of rouble and foreign currency lending to individuals and firms increased, as did the total volume of lending.

The growth rates of rouble and foreign currency lending to individuals increase equally in response to a positive shock to oil prices. This possibly results from the measures taken by the Bank of Russia to restrict consumer foreign currency lending, which were implemented in 2013 (for more details on MPP measures in Russia and other countries, see the Appendix). By comparison, the growth rate of corporate foreign currency lending is more sensitive to oil market shocks than is 
rouble lending to legal entities. This is the result of firms' greater need for foreign currency liquidity for international debt repayment and the increased opportunities they have to raise foreign currency funding.

Table 2. Oil price shock elasticity of Russia's credit cycle indicators

\begin{tabular}{lll} 
Credit cycle indicator & Elasticity & Maximum effect \\
\hline Rouble lending to individuals & 0.2236 & 15 months \\
\hline Foreign currency lending to individuals & 0.2424 & 22 months \\
\hline Share of overdue rouble loans to individuals & -0.0138 & 15 months \\
\hline Share of overdue foreign currency loans to individuals & -0.0714 & 21 months \\
\hline Rouble lending to legal entities & 0.0782 & 27 months \\
\hline Foreign currency lending to legal entities & 0.2136 & 7 months \\
\hline Share of overdue rouble loans to legal entities & -0.0165 & 18 months \\
\hline Share of overdue foreign currency loans to legal entities & insignificant & \\
\hline Total rouble lending level & 0.0872 & 26 months \\
\hline Total foreign currency lending level & 0.1851 & 7 months \\
\hline Overall lending level & 0.0857 & 30 months \\
\hline $\begin{array}{l}\text { Share of foreign currency loans to individuals in the total } \\
\text { portfolio volume }\end{array}$ & 0.0359 & 18 months \\
\hline $\begin{array}{l}\text { Share of foreign currency loans to legal entities in the total } \\
\text { portfolio volume }\end{array}$ & 0.0284 & 21 months \\
\hline Share of foreign currency loans in the total portfolio volume & 0.0339 & 20 months \\
\hline Corporate sector external debt & 0.1194 & 2 quarters \\
\hline Ratio of non-financial private sector loans to GDP & -0.2119 & 5 quarters \\
\hline
\end{tabular}

Source: author's calculations

The growth of oil prices in the global commodity market accelerates the accumulation of external debt in the corporate sector and leads to an economywide increase in the share of foreign currency loans. The effect of the growth of foreign debt manifests itself six months after the shock.

Although positive oil market shocks lead to an increase in the overall level of overdue debt and an expansion of the loan portfolio, the share of overdue debt decreases, which may demonstrate an improvement in the overall solvency of economic agents. Hence, the existence of a statistically and economically significant correlation between commodity prices and the share of overdue debt demonstrates the dependence of the Russian banking sector on external global conditions, which, in turn, could lead to the risk of financial instability in the event of a negative oil price shock.

The growth rate of the share of loans to the private non-finance sector as a \% of GDP decreases within the first two years, which can probably be explained by the fact that the increase in the inflow of foreign currency earnings to the country influences the level of nominal GDP. This trend is more in line with the experience of emerging markets that have less developed financial markets and lag behind advanced economies in terms of the overall credit burden of the economy. 
We also assessed the sensitivity of Russia's financial cycle parameters during a period of relatively homogeneous monetary policy (Polbin, 2017; Pestova, 2017): before the adoption of the inflation targeting (IT) regime in November 2014 (Figure 2). Assessment of empirical data in the January 2004-November 2014 period indicates a higher oil price elasticity for most lending indicators (the key credit risk indicators out of those in Table 2 are assessed), including the foreign currency predominance ratios, as compared to the elasticity of the same indicators over the entire assessment horizon (2004-2017). This suggests that the transition to an inflation targeting regime could have contributed to the reduced dependence of Russia's financial indicators on external shocks.

Figure 2. Oil price elasticity of key lending risk indicators for 2004-2014 and 2004-2017

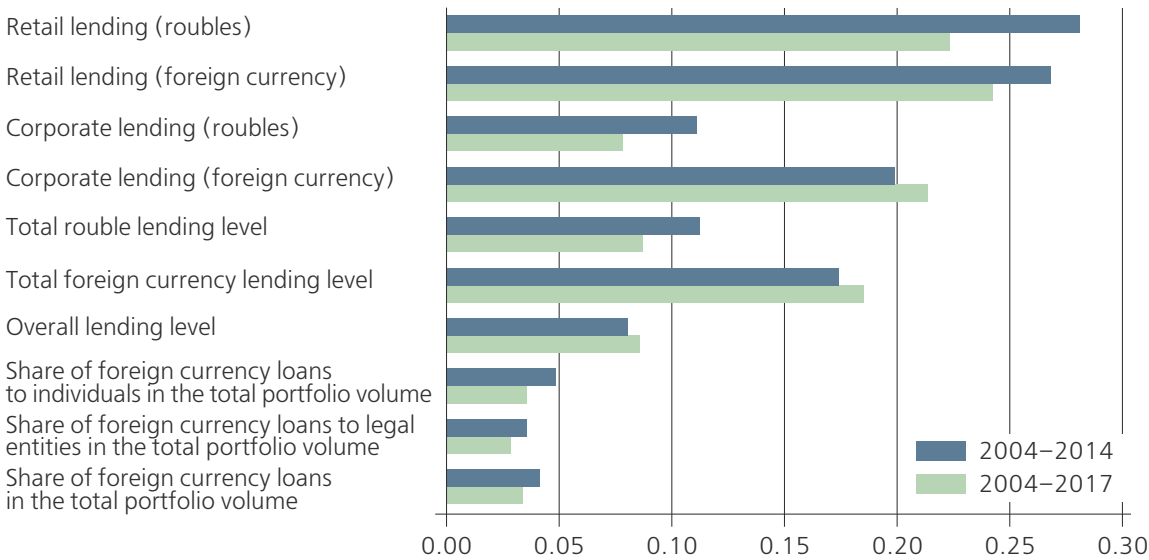

Source: author's calculations

\subsection{Columbia}

Like Russia's economy, the economy of Columbia is largely oriented towards the export of oil and petroleum products: in 2006-2017, the average share of this export category amounted to $37 \%$ (Figure 3 ).

At the same time, it should be noted that, throughout the past decade, the economic authorities of Columbia have made extensive use of macroprudential regulation tools to protect the national economy from external shocks (Vargas et al., 2017; Gómez et al., 2017). For example, Columbia receives the highest score of all the countries considered in the 'macroprudential policy index' developed by Cerutti et al. (2017) on the basis of information concerning the number of MPP tools used by economic authorities (see Figure 8 below and Table 1 in the Appendix).

A higher index demonstrates a more substantial level of MPP tool implementation. It can be observed that, among the countries considered in this study, Chile, Columbia, and Canada have the highest levels of macroprudential regulation. 
Table 3. Oil price shock elasticity of Columbia's credit cycle indicators

\begin{tabular}{lll} 
Credit cycle indicator & Elasticity & Maximum effect \\
\hline Overall lending level & 0.0683 & 31 months \\
\hline Share of overdue debt & insignificant & \\
\hline Consumer lending & 0.1197 & 20 months \\
\hline Share of overdue consumer loans & -0.0037 & 2 months \\
\hline Corporate lending & 0.0564 & 33 months \\
\hline Share of overdue corporate loans & insignificant & \\
\hline Private sector's external debt & -0.1078 & 9 months \\
\hline Ratio of non-financial private sector loans to GDP & -0.0362 & 3 quarters \\
\hline Foreign currency lending & -0.4804 & 2 quarters \\
\hline
\end{tabular}

Source: author's calculations

Figure 3. Columbia's export structure in 2006-2017 (\%)

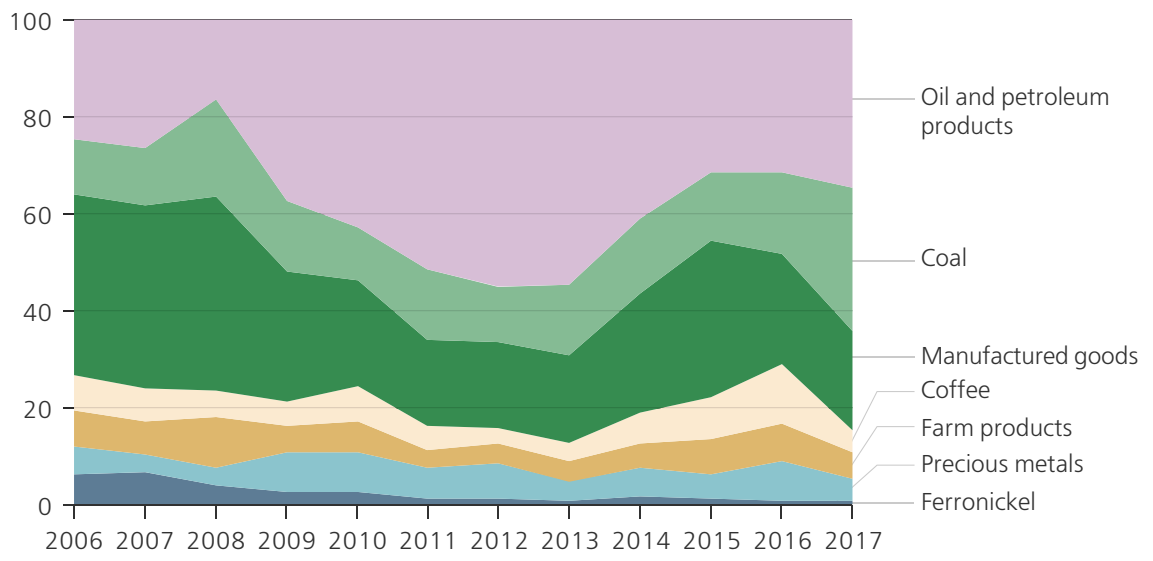

Source: National Administrative Department of Statistics of Columbia

According to BVAR assessment results for Columbia, the reaction of its sovereign risk premium and the exchange rate of the Columbian peso to growth in oil prices is similar to that of Russia (see Figure 2 in the Appendix). At the same time, the dynamics of interest rates demonstrate the tightening of financial market conditions during the growth phase of the commodity cycle. Increased borrowing costs in the domestic market in response to the improved terms of trade may be explained by the implementation of an inflation targeting policy and the extensive use of MPP tools throughout the period covered by this study. ${ }^{12}$ Despite increased interest rates, lending indicators demonstrate growth during the period of higher oil

\footnotetext{
${ }^{12}$ Besides the implementation of macroprudential policies, the specifics of Columbia's economic structure might have influenced the nature of the correlations observed. During the period covered by this study, the economy of Columbia remained relatively closed compared to that of other Latin American countries (Vargas et al., 2017). In connection with this, the dynamics of key macroeconomic indicators (including inflation) are determined more by the condition of domestic demand than by terms of trade (via the currency exchange rate channel) or the rigidity level of financial conditions in the global market. The role of the non-tradable sector remains significant.
} 
prices, which may signify the incomplete isolation of the country's financial sector from the effects of the global energy resource market, as well as the narrow range of MPP tools, which do not influence the overall lending level, but only specific market segments. The behaviour of the foreign debt indicators of the private sector and the overall level of foreign currency lending demonstrate the effectiveness of the use of restrictions on creating external and foreign currency debt (for more details, see the Appendix): the change rate of those indicators decreases if oil price growth accelerates (Figure 2 in the Appendix, Table 3).

\subsection{Chile}

Chile specialises in the export of copper: in 2003-2017, the average share of this export item amounted to $54 \%$ of the country's total export volume (Figure 4).

The extensive use of macroprudential regulation in Chile (Cerutti et al. 2017; see Figure 8 below) influences the reaction of market interest rates to the increase in copper prices that we obtained as a result of BVAR assessment. Interest rates grow when copper prices increase, although this effect manifests itself with a significant lag of around two years (Figure 3 in the Appendix). The initial impulse for the strengthening of the Chilean peso fades away 18 months after the shock; however, gradual tightening of monetary market conditions spurs an inflow of foreign capital and leads to the strengthening of the national currency. The reaction of the growth rate of the overall lending level and corporate lending to changes in the price of copper is insignificant overall. On the other hand, the indicator of lending to individuals demonstrates a clear positive response to the commodity market impulse, which corresponds with the high mortgage market risk level of Chile noted in the article by Cifuentes et al. (2017). Moreover, positive copper price shocks lead to faster growth in foreign currency lending and the overall level of foreign debt, which demonstrates the vulnerability of the country's economy to external shocks.

Figure 4. Chile's export structure in 2003-2017 (\%)

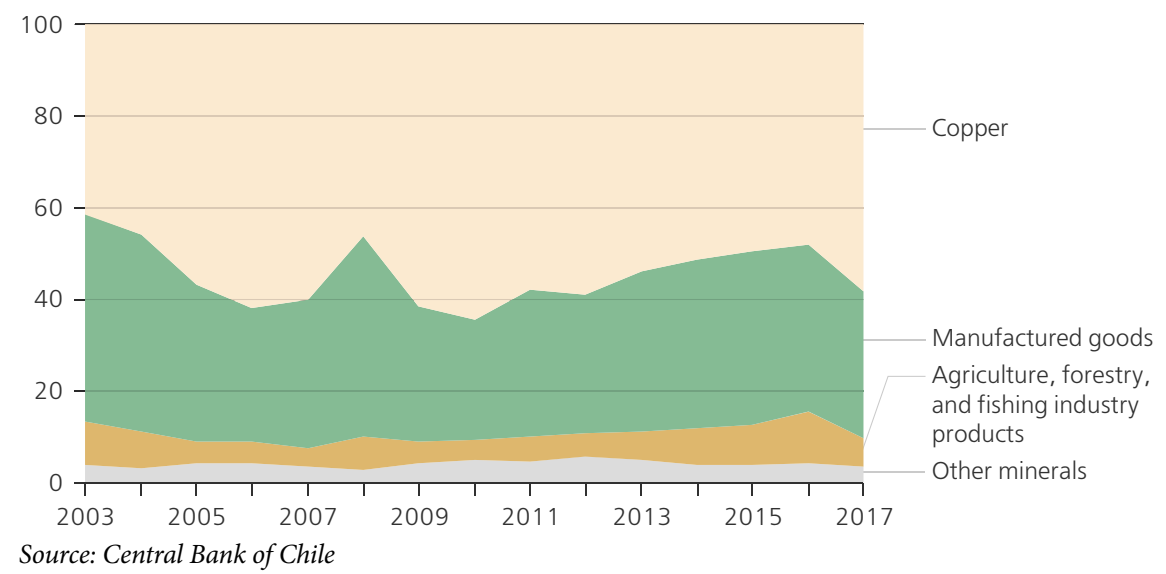


Table 4. Copper price shock elasticity of Chile's credit cycle indicators

\begin{tabular}{lll} 
Credit cycle indicator & Elasticity & Maximum effect \\
\hline Overall lending level & insignificant & \\
\hline Consumer lending & 0.0463 & 9 quarters \\
\hline Corporate lending & insignificant & \\
\hline External debt & 0.0481 & 3 quarters \\
\hline Ratio of non-financial private sector loans to GDP & -0.0687 & 7 quarters \\
\hline Foreign currency lending & 0.2942 & 10 quarters \\
\hline
\end{tabular}

Source: author's calculations

\subsection{Brazil}

The fact that no single commodity category has predominated in the structure of the country's exports over the past two decades is a peculiarity of Brazil's economy (Figure 5). In general, over the period 2000-2017, Brazil exported metals, crude oil, and food products. Use of the composite commodity index of the Bank of Brazil (reflecting the dynamics of prices for Brazil's various export items) gave insignificant results: the impulse responses of credit cycle parameters to commodity price shocks remained insignificant.

Figure 5. Brazil's export structure in 2000-2017 (\%)

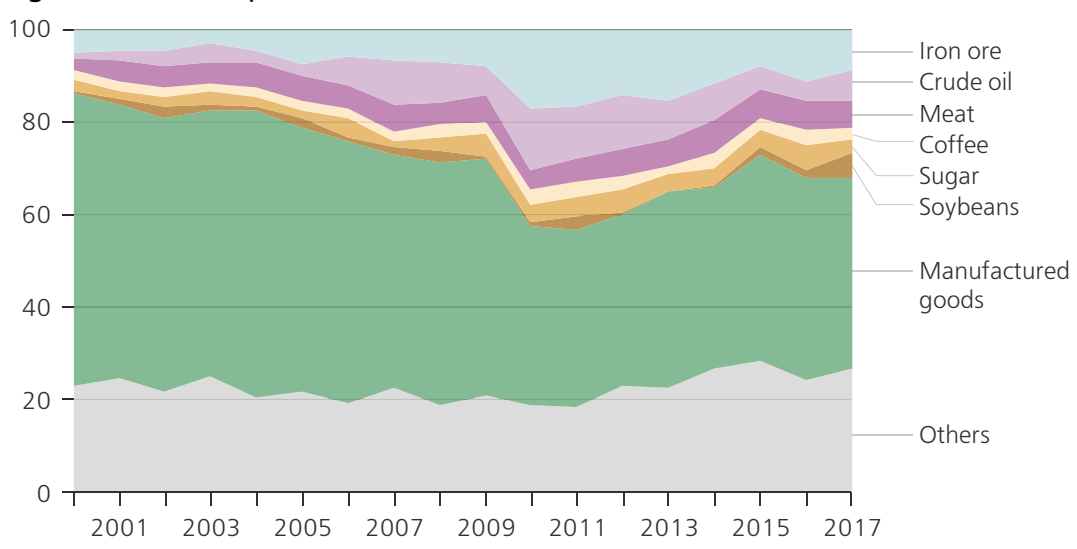

Source: Ministry of Development, Industry, and Foreign Trade of Brazil

Table 5. Iron ore price shock elasticity of Brazil's credit cycle indicators

\begin{tabular}{lll} 
Credit cycle indicator & Elasticity & Maximum effect \\
\hline Overall lending level & 0.0804 & 5 quarters \\
\hline Consumer lending & insignificant & \\
\hline Corporate lending & 0.1213 & 5 quarters \\
\hline Private sector's external debt & -0.1290 & 13 quarters \\
\hline Ratio of non-financial private sector loans to GDP & 0.0898 & 13 quarters \\
\hline Foreign currency lending & 0.2178 & 2 quarters \\
\hline Share of foreign currency loans in the total portfolio volume & 0.1168 & 10 quarters \\
\hline
\end{tabular}

Source: author's calculations 
That said, statistically significant lending indicator responses to iron ore price shocks have been obtained, although the average export of this commodity in 2000-2017 amounted to as little as 9\% of the total volume of exports from the country (Table 5). In other words, change in the situation on the global iron ore market is a source of risk for the Brazilian financial market.

According to Table 5, most of the credit cycle indicators change procyclically with the commodity cycles: lending to firms, overall lending, foreign currency lending, loan dollarisation, and the private non-finance sector loans-to-GDP ratio grow in response to improved terms of trade. The reaction of consumer lending to global metal market shocks turned out to be insignificant (Figure 4 in the Appendix), which may be connected with the effect of car loan market regulation measures (Gambacorta and Murcia, 2017). At the same time, most MPP measures were implemented for a short period (De Moura and Bandeira, 2017; Barroso et al., 2017).

Thus, estimates obtained using a long timeframe demonstrate that the national financial system of Brazil is significantly dependent on external conditions.

\subsection{Canada and Australia}

This section is devoted to analysis of the relationship between commodity and credit cycles in resource-based economies with a high level of development. Advanced economies have diversified economic structures (Figure 6), a longterm history of interest rate management, and deep financial markets. As our analysis confirms (see below), these characteristics make it possible to protect national economies from global market risks and reduce the sensitivity of internal macroeconomic variables to external sector shocks.

It has traditionally been assumed that, from a historical perspective, the central banks of advanced economies have had more opportunities to pursue countercyclical monetary policies, while central banks in emerging market economies were more procyclical (Kaminsky et al., 2005). Significant changes in the content of economic policies pursued by emerging market economies occurred only during the global financial crisis of 2007-2009 (Coulibaly, 2012), promoted by financial reforms and the switch to an inflation targeting policy.

According to the results of this study, interest rates in Australia increase during the growth phase of a commodity cycle (Figure 6 in the Appendix). No significant reaction by Canadian interest rates to the growth of oil prices has been detected (Figure 5 in the Appendix). At the same time, Canada, like Chile and Columbia, makes extensive use of MPP tools (Cerutti et al., 2017). Canadian macroprudential policy is mainly aimed at reducing risks in the housing loan market (Allen et al., 2017).

Tables 6-7 demonstrate that the ability of the financial authorities of Canada and Australia to pursue monetary and macroprudential policies 
aimed at countercyclical stabilisation allows them to react promptly to external challenges and effectively influence lending dynamics. In Canada and Australia, growth of commodity prices is accompanied by a decrease in the growth rates of the key financial risk indicators, including the overall level of lending, its specific components, foreign debt, and the share of foreign currency loans. Consequently, major commodity exporters are less vulnerable to terms of trade shocks.

Figure 6. Canada's export structure in 2000-2017 (\%)

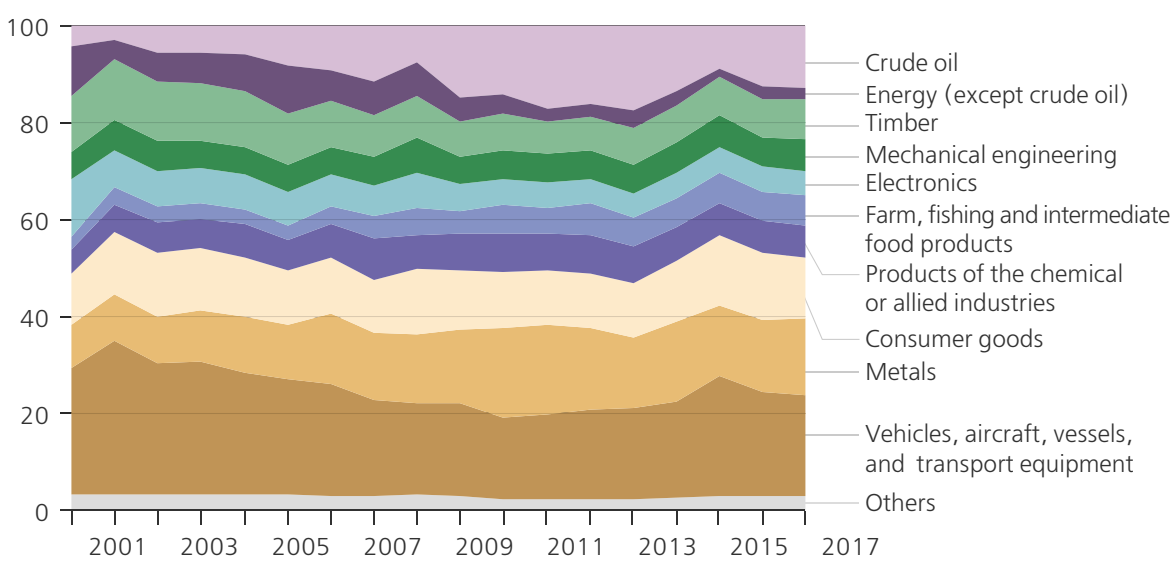

Source: Statistics Service of Canada

Table 6. Oil price shock elasticity of Canada's credit cycle indicators

\begin{tabular}{lll} 
Credit cycle indicator & Elasticity & Maximum effect \\
\hline Overall lending level & -0.0453 & 4 quarters \\
\hline Consumer lending & insignificant & \\
\hline Corporate lending & -0.0883 & 4 quarters \\
\hline External debt & 0.0509 & 1 quarter \\
\hline Ratio of non-financial private sector loans to GDP & -0.0836 & 4 quarters \\
\hline Foreign currency lending & insignificant & \\
\hline Share of foreign currency loans in the total loan portfolio volume & -0.0983 & 2 quarters \\
\hline
\end{tabular}

Source: author's calculations

Table 7. Coal price shock elasticity of Australia's credit cycle indicator

\begin{tabular}{lll} 
Credit cycle indicator & Elasticity & Maximum effect \\
\hline Overall lending level & -0.0365 & 7 quarters \\
\hline Consumer lending & -0.1444 & 7 quarters \\
\hline Corporate lending & -0.0392 & 6 quarters \\
\hline Private sector's external debt & -0.0774 & 5 quarters \\
\hline Ratio of non-financial private sector loans to GDP & -0.0628 & 5 quarters \\
\hline
\end{tabular}

Source: author's calculations 
Compared to emerging market countries, where national financial markets have historically been quite narrow, with the result that economic agents have been forced to turn to international loan markets and raise foreign currency financing, advanced economies are relatively protected from foreign currency predominance in their financial systems. The 'high base' effect also comes into play: advanced economies are highly saturated with loans, as a result of which payment balance shocks caused by changes in global commodity markets influence the dynamics of internal macrovariables to a lesser extent. Thus, in advanced economies, it may be enough to use monetary regulation tools to counter external market threats (including terms of trade fluctuations).

\section{Cross-country comparisons: impact of commodity market shocks on financial cycles}

This study has established a statistically and economically significant correlation between the dynamics of commodity and financial cycle indicators in resource-based economies. In commodity exporters, global commodity market shocks trigger a significant reaction from financial cycle indicators, which confirms the dependence of the national financial markets of resource-based economies on external economic conditions.

It may be noted that, if the export share of a certain item grows, the overall structure of the exports of the countryin question shows an increasein the sensitivity of its sovereign risk premium and exchange rate to commodity price shocks (Figure $7^{13}$ ). This correlation is most typical for emerging markets (Brazil, Columbia, Chile, and Russia) due to the low diversification of their economies and the significant sensitivity of balances of payments and investors' perception of national economy risks to changes in terms of trade. In advanced economies (Canada and Australia), the reaction of sovereign risk premiums and currency exchange rates is limited.

In Chile, Russia, and Columbia, which have the highest resource dependence of all the countries considered (with shares of the key export item in the overall volume of exports amounting to $58 \%, 42 \%$, and $35 \%$ respectively), the commodity price elasticities (in modules) of sovereign CDS spreads and currency exchange rates vary within the ranges of 53\%-109\% and $17 \%-30 \%$ respectively. In Brazil, which is a commodity exporter, but one which supplies different types of commodities to the global market (not only energy resources, but also metals and food), the reactions of the currency exchange rate to commodity market shocks are insignificant in value. At the same time, Brazil's sovereign CDS spread is subject to considerable fluctuation, which may be explained by prospective investors' perceptions of the national economies of developing countries

\footnotetext{
${ }^{13}$ Sensitivity indicators in column charts are calculated as the maximum elasticity of some variables against shocks in other variables based on the results of impulse function calculations.
} 
in general as exposed to global commodity market risks. In Canada and Australia - advanced economies with more diversified export structures - no dependence of risk premiums on the dynamics of global energy resource markets has been identified, and the elasticity of currency exchange rates is lower than in developing countries in general.

Figure 7. The correlation between commodity exports and the commodity price elasticities of sovereign risk premium and currency exchange rate by country

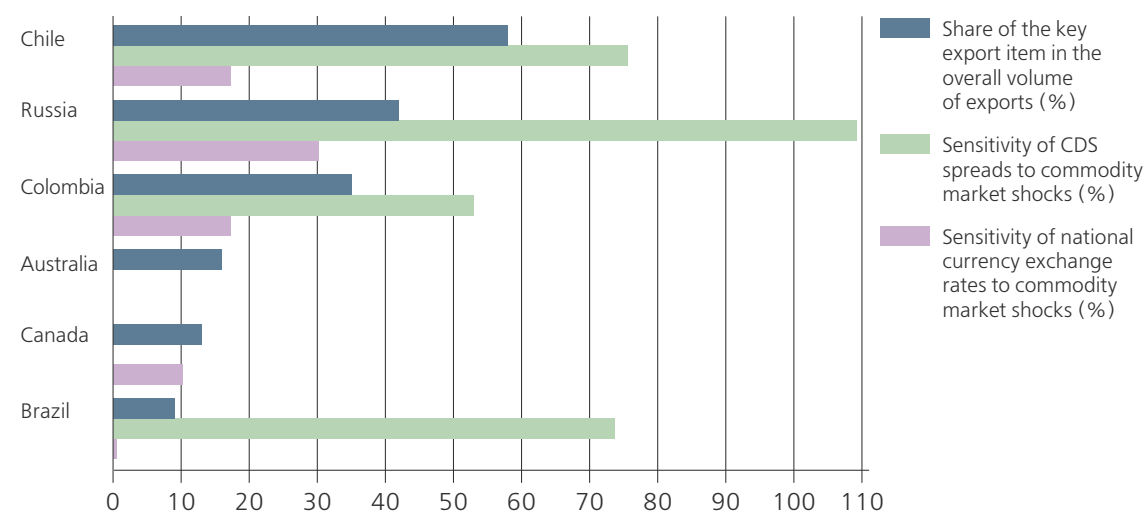

Source: author's calculations

Figure 8. The correlation between MPP index levels and the sensitivity of interest rates to commodity market shocks

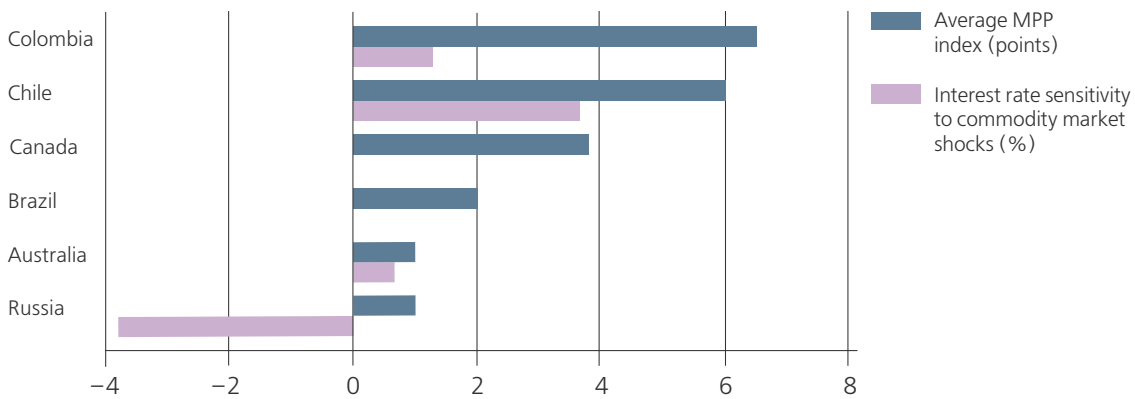

Source: author's calculations

This research shows that in Canada and Australia acceleration of commodity price growth leads to a slowdown in credit cycle growth rates. Higher interest rates during the growth phase of a commodity cycle help to suppress a lending boom in the event that the situation in the global commodity markets improves. In Canada and Australia, the reaction we have observed from lending conditions apparently stems from a high level of financial market development and broad opportunities for financial authorities to pursue effective countercyclical stabilisation policies. 
Based on the results of this analysis, it can be concluded that, to suppress a boom in the credit market, emerging market economies should supplement their monetary policies with macroprudential regulatory tools: countries with a higher level of MPP tool use show the lending price growth required for the suppression of financial cycles (Figure 8). Cerutti et al. (2017) use the average MPP index for 2000-2013 as the MPP index. It may be noted that, in developing countries with a higher level of MPP tool implementation (Chile, Columbia), interest rates grow in response to positive global market commodity price shocks, while in developing countries that use MPP instruments less extensively (Brazil, Russia), growth of oil prices is accompanied by easing of financial conditions (Russia) or the absence of a significant reaction from lending prices (Brazil).

In addition, analysis of elasticities shows that the sensitivity of general and foreign currency lending dynamics to commodity price shocks is lower (Figure 9) in developing countries with a higher level of use of MPP tools (Chile and Colombia), another piece of evidence supporting the more extensive introduction of macroprudential policies in commodity-producing emerging market economies. In Brazil and Russia, ${ }^{14}$ where the level of MPP tool application is lower, overall lending growth rates are observed to be generally more sensitive to commodity market shocks ( $8.3 \%$ on average in Russia and Brazil against $5.5 \%$ on average in Chile and Columbia). In Columbia, which uses the widest range of MPP tools, the rate of foreign currency lending growth decreases in response to improvement in the terms of trade.

Figure 9. The correlation between MPP index values and the sensitivity of general and foreign currency lending in emerging market economies

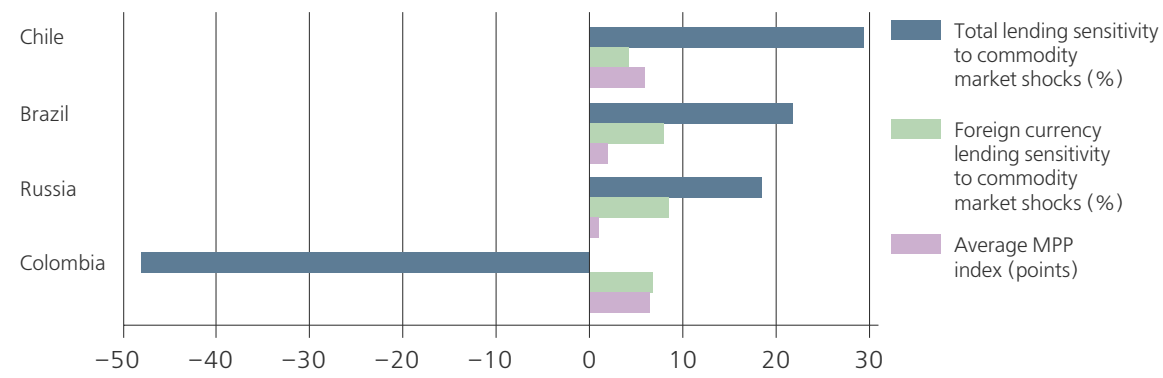

Source: author's calculations

Analysis of historical data shows that a correlation between changes in the main parameters of commodity cycles (oil prices) and financial cycles (exchange rate, risk

\footnotetext{
${ }^{14}$ Chile and Columbia also use fiscal rules relatively extensively, to a similar degree to Canada (see the Appendix for more details), which probably also helps restrict the dependence of the national financial system's parameters on external shocks.
} 
premium, lending, and foreign currency lending) is typical for Russia. An important step in reducing the exposure of financial sector indicators to external shocks is transition to a countercyclical economic policy (inflation targeting and fiscal rules).

The Bank of Russia's current macroprudential policy measures are intended to reduce lending growth rates, especially in unsecured consumer lending, the segment fraught with the highest risks. To that end, the Bank of Russia uses risk ratios depending on the total cost of loans (TCL). Another source of risks to financial stability is the problem of foreign currency predominance in the banking sector. The Bank of Russia adjusts the risk ratios for foreign currency loans to legal entities with insufficient currency revenue to restrict this type of lending (see the Appendix for more details).

Currently, the Bank of Russia is also working on introducing a debt burden ratio (DBR). ${ }^{15}$ This ratio will be calculated from 1 October 2019 (Bank of Russia, 2019). The Bank of Russia's current macroprudential regulation measures are aimed at limiting the key risks identified in this study.

\section{Summary and conclusions}

The influence of global commodity market parameters on the dynamics of macroeconomic indicators and financial markets in commodity-exporting countries has been widely discussed in the literature. Growth in commodity prices leads to accelerated debt burden accumulation in resource-based economies and, in the event of a sharp turnaround in commodity prices, to significant deleveraging and deterioration of economic agents' ability to fulfil their obligations. All of the above is connected with the growth of systemic risks and threats to the overall stability of financial systems.

This study has confirmed these observations. This paper demonstrates that a higher commodity price leads to increased growth in overall lending, foreign currency lending, and external debt in the majority of the countries analysed, including Russia. Moreover, in Russia and Brazil, positive shocks to commodity prices have triggered growth in the share of FX loans to households and businesses. The improvement of global terms of trade for commodity exporters leads to a decrease in the share of overdue loans. Despite the relatively insignificant economic effect of this correlation, decreases in commodity prices may entail growth of the share of non-performing loans, which is connected with nonpayment risks and demonstrates the dependence of national financial systems on external conditions.

A higher degree of resource dependence leads to an increase in economic volatility and in the sensitivity of such economic cycle indicators as currency exchange rate and sovereign risk premium. In advanced economies (Canada and Australia), the influence of the commodity cycle on the financial cycle is

${ }^{15}$ See http://cbr.ru/Press/event/?id=2678. 
insignificant due to the diversified nature of their economic structures, the ability of monetary authorities to pursue countercyclical monetary policies, and a relatively higher historical level of financial market development.

In general, the emerging market economies of Brazil, Chile, Columbia and Russia demonstrate procyclicality in commodity and financial cycle parameter changes. Developing countries that use MPP more extensively have lower procyclicality of commodity price dynamics and lower rates of loan load accumulation.

To reduce the exposure of national economic and financial system parameters to external market shocks (including from global commodity markets), the economic authorities of emerging market countries should develop national financial markets and pursue countercyclical macroprudential policies in addition to their monetary policies. The Bank of Russia has recently been developing macroprudential regulatory tools more extensively.

As an area for future research, we propose including explicit fiscal and macroprudential policy variables in the model, which will contribute to our understanding of the role of countercyclical economic regulation in reducing the interrelationships between commodity and financial cycle parameters in commodity-producing countries

Appendix is available at http://rjmf.econs.online/en; dx.doi.org/10.31477/rjmf.201903.38

\section{References}

Agarwal, I., Duttagupta, R. and Presbitero, A. (2017). International Commodity Prices and Domestic Bank Lending in Developing Countries. IMF Working Paper, N 279.

Alessi L. and Detken C. (2018). Identifying Excessive Credit Growth and Leverage. Journal of Financial Stability, 35, pp. 215-225. doi: 10.1016/j.jfs.2017.06.005

Allen, J., Grieder, T., Peterson, B. and Roberts, T. (2017). The Impact of Macroprudential Housing Finance Tools in Canada. Journal of Financial Intermediation. Article in press. doi: 10.1016/j.jfi.2017.08.004

Alodayni, S. (2016). Oil Prices, Credit Risks in Banking Systems, and Macro-Financial Linkages Across GCC Oil Exporters. International Journal of Financial Studies, 4(4), pp. 1-14. doi: 10.3390/ijfs 4040023

Bańbura, M., Giannone, D. and Reichlin, L. (2010). Large Bayesian Vector Auto Regressions. Journal of Applied Econometrics, 25(1), pp. 71-92. doi:10.1002/jae.1137

Bank for International Settlements (2019). Annual Economic Report 2019.

Bank of Russia (2017). The Role of Macroprudential Policy in Conditions of the Correlation Between Commodity Cycles with Capital Flows and Financial Cycle. Analytical Note of the Financial Stability Department. [In Russian]. Available at: http://www.cbr.ru/ Content/Document/File/16743/analytic_note_170808.pdf [accessed on 25 July 2019]. 
Bank of Russia (2019). Financial Stability Review, 1.

Barroso, J., Gonzalez, R. and Doornik, B. (2017). Credit Supply Responses to Reserve Requirement: Loan-Level Evidence from Macroprudential Policy. BIS Working Papers, N 674.

Basher, S.A., Haug, A.A. and Sadorsky, P. (2012). Oil Prices, Exchange Rates and Emerging Stock Markets. Energy Economics, 34(1), pp. 227-240. doi: $10.1016 /$ j.eneco.2011.10.005

Bergholt, D., Larsen, V.H. and Seneca, M. (2019). Business Cycles in an Oil Economy. Journal of International Money and Finance, 96, pp. 283-303. doi: 10.1016/j.jimonfin.2017.07.005

Bernanke, B.S. and Boivin, J. (2003). Monetary Policy in a Data-Rich Environment. Journal of Monetary Economics, 50(3), pp. 525-546. doi: 10.1016/S0304-3932(03)00024-2

Bernanke, B.S., Boivin, J. and Eliasz, P. (2005). Measuring the Effects of Monetary Policy: A Factor-Augmented Vector Autoregressive (FAVAR) Approach. The Quarterly Journal of Economics, 120(1), pp. 387-422.

Blake, A. and Mumtaz, H. (2017). Applied Bayesian Econometrics for Central Bankers. Bank of England Centre for Central Banking Studies Technical Books. Available at: https://www.bankofengland.co.uk/ccbs/applied-bayesian-econometricsfor-central-bankers-updated-2017 [accessed on 25 July 2019].

Bruno, V., Shim, I. and Shin, H.S. (2017). Comparative Assessment of Macroprudential Policies. Journal of Financial Stability, 28, pp. 183-202. doi: 10.1016/j.jfs.2016.04.001

Cerutti, E., Claessens, S. and Laeven, L. (2017). The Use and Effectiveness of Macroprudential Policies: New Evidence. Journal of Financial Stability, 28(C), pp. 203-224. doi: 10.1016/j.jfs.2015.10.004

Christiano, L.J., Eichenbaum, M. and Evans, C.L. (1999). Monetary Policy Shocks: What Have We Learned and to What End? In: J. B. Taylor and M. Woodford, eds. Handbook of Macroeconomics, Vol. 1, Part A, pp. 65-148. doi: 10.1016/S1574-0048(99)01005-8

Chun, A. (2011). Expectations, Bond Yields and Monetary Policy. Review of Financial Studies, 24(1), pp. 208-247. doi: 10.1093/rfs/hhq090

Cifuentes, R., Claro, S. and Jara, A. (2017). Macroeconomic and Financial Volatility and Macroprudential Policies in Chile. BIS Papers, 94, pp. 87-98.

Cizel, J., Frost, J., Houben, A. and Wierts, P. (2016). Effective Macroprudential Policy: Cross-Sector Substitution from Price and Quantity Measures. IMF Working Paper, N 94.

Coudert, V., Couharde, C. and Mignon, M. (2015). On the Impact of Volatility on the Real Exchange Rate - Terms of Trade Nexus: Revisiting Commodity Currencies. Journal of International Money and Finance, 58(C), pp. 110-127. doi: 10.1016/j.jimonfin.2015.08.007

Coulibaly, B. (2012). Monetary Policy in Emerging Market Economies: What Lessons from the Global Financial Crisis? Board of Governors of the Federal Reserve System International Finance Discussion Papers, N 1042. 
Dauvin, M. (2014). Energy Prices and the Real Exchange Rate of Commodity-Exporting Countries. International Economics, 137, pp. 52-72. doi: 10.1016/j.inteco.2013.11.001

De Moura, M. and Bandeira, F. (2017). Macroprudential Policy in Brazil. BIS Papers, 94, pp. 77-86.

Demeshev, B. and Malakhovskaya, O. (2016). BVAR Mapping. Applied Econometrics, 43, pp. 118-141. [In Russian].

Ftiti, Z., Kablan, S. and Guesmi, K. (2016). What Can We Learn About Commodity and Credit Cycles? Evidence from African Commodity-Exporting Countries. Energy Economics, 6, pp. 313-324. doi: 10.1016/j.eneco.2016.10.011

Gambacorta, L. and Murcia, A. (2017). The Impact of Macroprudential Policies and Their Interaction with Monetary Policy: An Empirical Analysis Using Credit Registry Data. BIS Working Papers, N 636.

Gómez, E., Lizarazo, A., Mendoza, J. and Murcia, A. (2017). Evaluating the Impact of Macroprudential Policies on Credit Growth in Colombia. BIS Working Papers, N 634.

González, A., Hamann, F. and Rodríguez, D. (2015). Macroprudential Policies in a Commodity Exporting Economy. BIS Working Papers, N 506.

Hegerty, S. W. (2016). Commodity-Price Volatility and Macroeconomic Spillovers: Evidence from Nine Emerging Markets. North American Journal of Economics and Finance, 35, pp. 23-37. doi: 10.1016/j.najef.2015.10.014

Ito, K. (2012). The Impact of Oil Price Volatility on the Macroeconomy in Russia. The Annals of Regional Science, 48(3), pp. 695-702. doi: 10.1007/s00168-010-0417-1

Kaminsky, G., Reinhart, C. and Vegh, C. (2005). When It Rains, It Pours: Procyclical Capital Flows and Macroeconomic Policies. NBER Macroeconomics Annual, 19, pp. 11-53.

Kinda, T., Mlachila, M. and Quedraogo, R. (2016). Commodity Price Shocks and Financial Sector Fragility. IMF Working Paper, N 12.

Kolb, B. (2016). Codes on Bayesian VARs Using the Gibbs Sampler. Available at: http://www.bkolb.eu/codes/ [accessed on 25 July 2019].

Krieger, K., Mauck, N. and Chen, D. (2012). VIX Changes and Derivative Returns on FOMC Meeting Days. Financial Markets and Portfolio Management, 26(3), pp. 315-331. doi: 10.1007/s11408-012-0191-4

Lomivorotov, R. (2014). Impact of External Shocks and Monetary Policy on Russian Economy. Voprosy Ekonomiki, 11, pp. 122-139. [In Russian]. doi:10.32609/0042-8736-2014-11-122-139

Makin, A. (2013). Commodity Prices and the Macroeconomy: An Extended Dependent Economy Approach. Journal of Asian Economics, 24(C), pp. 80-88. doi: 10.1016/j.asieco.2012.10.001

Malakhovskaya, O. and Minabutdinov, A. (2013). Dynamic Stochastic General Equilibrium Model of the Export-Oriented Economy. Higher School of Economics Preprint, WP12/2013/04. [In Russian]. Available at: https://wp.hse.ru/ data/2014/02/26/1329936952/WP12_2013_04_ff.pdf [accessed on 25 July 2019]. 
Martínez, G.O. (2008). Inflation Targeting. In: A Festschrift in Honour of David Dodge's Contributions to Canadian Public Policy - 2008 Conference. Bank of Canada, pp. 85-103. Available at: https://www.bankofcanada.ca/wp-content/uploads/2010/09/ martinez.pdf [accessed on 25 July 2019].

Menna, L. and Tobal, M. (2018). Financial and Price Stability in Emerging Markets: The Role of the Interest Rate. BIS Working Papers, N 717.

Moiseev, S. and Lobanova, M. (2013). Terminology - Main Aspects: Macroprudential Policy Concept. Dengi i Kredit, 7, pp. 46-54. [In Russian] Available at: https://rjmf.econs.online/archive/2013/7/ [accessed on 25 July 2019].

Moreno, C., Saavedra, C. and Ulloa, B. (2014). Commodity Price Cycles and Financial Stability. Working Papers of the Central Bank of Chile, N 738.

Pestova, A. (2017). Monetary Policy Regimes in Russia: Guidelines for Further Quantitative Studies. Voprosy Ekonomiki, 4, pp. 38-60. [In Russian]. doi:10.32609/0042-8736-2017-4-38-60

Pestova, A. and Mamonov, M. (2016). Estimating the Influence of Different Shocks on Macroeconomic Indicators and Developing Conditional Forecasts on the Basis of BVAR Model for the Russian Economy. Economic Policy, 11(4), pp. 56-92. [In Russian]

Polbin, A. (2017). Econometric Estimation of the Impact of Oil Prices Shock on the Russian Economy in VECM Model. Voprosy Ekonomiki, 10, pp. 27-49. [In Russian]. doi: 10.32609/0042-8736-2017-10-27-49

Rey, H. (2018). Dilemma not Trilemma: The Global Financial Cycle and Monetary Policy Independence. NBER Working Paper, N 21162.

Richter, B., Schularick, M. and Shim, I. (2018). The Macroeconomic Effects of Macroprudential Policy. BIS Working Papers, N 740.

Sinyakov, A. and Khotulev, I. (2017). Optimal Monetary, Fiscal and Macroprudential Policy in Oil Exporting Economy. Dengi i Kredit, 9, pp. 58-66. [In Russian]. Available at: https://rjmf.econs.online/archive/2017/9/ [accessed on 25 July 2019].

Vargas, H., Cardoz, P. and Murcia, A. (2017). The Macroprudential Policy Framework in Colombia. BIS Papers, 94, pp. 103-128. 